\title{
FAKTOR YANG MEMPENGARUHI PREFERENSI REMAJA BALI DALAM KEINGINAN MEMILIKI JUMLAH ANAK IDEAL
}

\author{
I Gusti Ayu Agung Putri Krismayanthi ${ }^{1 *}$, Istiana Marfianti ${ }^{1}$, Putu Ayu Indrayathi ${ }^{1,2}$, Ni Made Ari Listiani ${ }^{3}$ \\ 1Center for Public Health Innovation, Fakultas Kedokteran, Universitas Udayana \\ 2 Departemen Kesehatan Masyarakat dan Kedokteran Pencegahan, FK, Unud \\ 3Badan Kependudukan dan Keluarga Berencana Perwakilan Provinsi Bali \\ *email: pkrismayanthi@gmail.com)
}

\begin{abstract}
ABSTRAK
Data Survei Demografi dan Kesehatan Indonesia (SDKI) tahun 2017 menemukan terjadinya penurunan TFR dari 2.60 anak per wanita menjadi 2.4 anak per wanita dan masih belum mencapai target nasional tahun 2018 sebesar 2.31 anak per wanita. Provinsi Bali menjadi salah satu provinsi dengan TFR terendah sebesar 2.2 anak per wanita. Tujuan penelitian ini adalah mengetahui faktor-faktor yang mempengaruhi preferensi remaja Bali memiliki jumlah anak ideal. Penelitian ini merupakan analisis data sekunder dari Survei Kinerja dan Akuntabilitas Program KKBPK (SKAP) tahun 2018 dengan rancangan cross-sectional. Besar sampel adalah 632 remaja belum kawin usia 15-24 tahun yang terdiri dari 334 remaja perempuan dan 298 remaja laki-laki. Variabel yang diteliti adalah jenis kelamin, umur, tempat tinggal, pendidikan, kuintil kekayaan, keterpaparan remaja terhadap informasi kesehatan reproduksi dan sumber informasi kependudukan dengan variabel terikatnya adalah keinginan keluarga menginginkan banyak anak (>2). Berdasarkan jenis kelaminnya, sebanyak 58.5\% remaja perempuan usia 15-24 tahun lebih menginginkan memiliki anak $>2$ dibandingkan remaja laki-laki (41.4\%). Hasil analisis multivariat menunjukkan faktor yang berhubungan secara signifikan yakni jenis kelamin $(\mathrm{p}=0.014, \mathrm{OR}=$ $1.722,95 \% \mathrm{CI}=1.115-2.593)$ dan televisi $(\mathrm{p}=0.043, \mathrm{OR}=1.729,95 \% \mathrm{CI}=1.017-2.937)$. Sementara faktor protektifnya adalah pamflet/brosur/leaflet $(\mathrm{p}=0.002, \mathrm{OR}=0.444,95 \% \mathrm{CI}=0.265-0.747)$. Simpulan yang dapat ditarik pada penelitian ini adalah preferensi remaja Bali dalam keinginannya memiliki jumlah anak ideal dipengaruhi oleh faktor internal seperti jenis kelamin dan eksternal yakni media massa seperti televisi.
\end{abstract}

Kata kunci: Preferensi remaja, jumlah anak ideal, remaja Bali, SKAP

\begin{abstract}
In the 2017 Indonesian Demographic and Health Survey (SDKI), found that a decrease in TFR from 2.60 children per woman to 2.4 children per woman and still had not reached the national target in 2018 of 2.31 children per woman. Bali Province is one of the provinces with the lowest TFR of 2.2 children per woman. The purpose of this study is to determine the factors that influence the preferences of Balinese adolescents to have the ideal number of children. This study is a secondary data analysis from the 2018 KKBPK Program Performance and Accountability Survey (SKAP) with a cross-sectional design. The sample size was 632 unmarried adolescents aged 15-24 years consisting of 334 female adolescents and 298 male adolescents. The variables studied were gender, age, place of residence, education, wealth quintile, adolescent exposure to reproductive health information and sources of population information with the dependent variable being the desire of the family to have many children $(>2)$. Based on sex, as many as $58.5 \%$ of adolescent girls aged $15-24$ years prefer to have many children $(>2)$ compared to boys (41.4\%). The results of multivariate analysis showed significantly related factors namely gender $(\mathrm{p}=0.014$, $\mathrm{OR}=1,722,95 \% \mathrm{CI}=1,115-2,593)$ and television $(\mathrm{p}=0.043, \mathrm{OR}=1,729,95 \% \mathrm{CI}=1,017-2,937)$. While the protective factor is pamphlets / brochures / leaflets $(\mathrm{p}=0.002, \mathrm{OR}=0.444,95 \% \mathrm{CI}=0.265-0.747)$. The conclusion that can be drawn in this study is the preference of Balinese adolescents in their desire to have an ideal number of children influenced by internal factors such as gender and external namely mass media such as television.
\end{abstract}

Keywords : Adolescent preference, ideal number of children, Balinese adolescents

PENDAHULUAN

Populasi dunia tahun 2019

dilaporkan mencapai 7,7 juta jiwa dengan rata-rata pertumbuhan penduduk sebesar 1,1\% dari tahun 2010 hingga 2019 (United nations population fund, 2017). Indonesia 
merupakan salah satu negara yang turut menyumbang tingginya populasi dunia. Jumlah penduduk Indonesia berdasarkan SUPAS (Survei Penduduk Antar Sensus) tahun 2015 sebanyak 255,18 juta jiwa dengan laju pertumbuhan penduduk 1,43\% dari tahun 2010-2015. Laju pertumbuhan penduduk (LPP) mengalami penurunan yang disebabkan adanya kebijakan pemerintah terkait program keluarga berencana (KB) yang mulai dilaksanakan di tahun 1980an. Meski di awal reformasi tahun 2000-2010 sempat mengalami peningkatan 0,05\% (Badan Pusat Statistik, 2015).

Terdapat tiga faktor utama yang mempengaruhi pertumbuhan penduduk yakni kelahiran (fertilitas), kematian (mortalitas) dan perpindahan (migrasi). Total fertility rate (TFR) Indonesia mengalami penurunan dari tahun 1991 dengan 3,03 anak per wanita usia subur menjadi 2,60 anak per wanita usia subur pada tahun 2002-2003. Sejak periode tersebut hingga tahun 2012, TFR Indonesia tidak mengalami perubahan (stagnan). Pada SDKI tahun 2017, TFR dilaporkan turun menjadi 2,4 anak per wanita usia subur. Data ini tidak jauh berbeda dengan laporan Survei Kinerja dan Akuntabilitas Program Keluarga Berencana dan Pembangunan Keluarga (SKAP KKBPK) tahun 2018 yaitu 2,38 anak per wanita usia subur (Badan Kependudukan dan Keluarga Berencana Nasional, 2018a). Meski demikian, capaian tersebut masih belum sesuai dengan target nasional di tahun 2018 yakni 2,31 anak per wanita usia subur (Badan Kependudukan dan Keluarga Berencana Nasional, 2018b).

Indonesia diperkirakan akan mencapai bonus demografi di tahun 2030 dan untuk itu diperlukan perencanaan yang matang dalam menghasilkan sumber daya manusia yang berkulitas. Laporan Sensus Penduduk (SP) tahun 2010, remaja 15-24 tahun jumlahnya telah mencapai 40,77 juta jiwa atau sekitar $17,16 \%$ dari total penduduk Indonesia (Badan Pusat Statistik, 2010). Saat ini diperkirakan 1 dari 4 penduduk Indonesia adalah pemuda atau sekitar 63,82 juta jiwa mengisi hampir seperempat penduduk (24,15\%) (Badan Pusat Statistik, 2018). Meskipun tidak mendominasi proporsi penduduk, jumlah tersebut akan sangat berarti jika diikuti dengan peningkatan kualitas. Menurut World Health Organization (WHO) remaja didefinisikan sebagai sebuah periode kehidupan dengan kebutuhan dan hak spesifik akan kesehatan dan perkembangannya (Badan Pusat Statistik, 2018). Pada tahap ini juga terjadi perkembangan pengetahuan dan kemampuan/keahlian, belajar pengendalian emosi dan membina suatu hubungan, serta memperoleh atribut dan kemampuan yang penting untuk menikmati masa remaja dan bersiap menuju kehidupan dewasa (The World Bank, 2006).

Remaja juga dapat diartikan sebagai suatu masa transisi dari anak menjadi dewasa atau untuk memulai kehidupan berkeluarga. Sehubungan dengan hal tersebut, dibutuhkan perencanaan yang tepat untuk menjadikan remaja sebagai sosok yang bertanggung jawab terhadap kehidupannya. Remaja memerlukan pemahaman yang tepat mengenai cara mempersiapkan keluarga yang berkualitas dilihat dari waktu yang 
tepat untuk menentukan anak dan jumlah yang diinginkan (fertility preferences). Hal ini secara langsung akan berpengaruh pada pertumbuhan penduduk dan perkembangan ekonomi suatu negara. Catherine Hakim dalam Preference Theory (2003) menyebutkan bahwa keinginan memiliki anak dan jumlah yang diinginkan dipengaruhi oleh gaya hidup, budaya, modernisasi dan pekerjaan/wanita karir atau non karir (ibu rumah tangga). Hasil penelitian di Kenya dan Indonesia memperlihatkan faktorfaktor yang berkaitan dengan preferensi jumlah anak seperti pendidikan, etnis, penggunaan metode kontrasepsi, umur, asal, pekerjaan dan tempat tinggal baik pada wanita yang sudah menikah maupun pada remaja (Lunani, 2014; Sari, 2015; Agushybana et al., 2019).

Memiliki anak di usia remaja selain memberikan dampak negatif dari sisi kesehatan, juga akan memberikan dampak negatif bagi perkembangan kehidupan remaja. Penelitian mengenai persepsi remaja terhadap keberadaan anak menunjukkan bahwa remaja yang memiliki anak di usia muda akan mempengaruhi kehidupan sosialnya. Hilangnya kesempatan untuk bergaul dengan teman sebaya, memiliki waktu luang yang terbatas, hilangnya kesempatan untuk berolahraga atau berkegiatan merupakan kondisi-kondisi yang diakibatkan oleh karena memiliki anak dari sudut pandang remaja (Herrman, 2008). Memiliki anak juga mengakibatkan remaja mengalami putus sekolah dan menimbulkan perasaan depresi, stres dan merasa dikucilkan
(Erfina et al., 2019).

Tidak adanya pengalaman dan persiapan yang dimiliki oleh remaja ketika masa transisi menjadi orang tua juga mengakibatkan munculnya masalah bagi remaja. Penelitian mengenai masa transisi menjadi seorang ibu memperlihatkan remaja cenderung mengalami permasalahan seperti adanya rasa penyesalan, merasa kehilangan, stres, putus asa, ketidakmampuan dalam merawat bayi (DeVito, 2010; Nicolas W. Cortes-Penfield, Barbara W. Trautner, 2017; Erfina et al., 2019). Dalam mengantisipai kondisi di atas, pemerintah melalui Badan Kependudukan dan Keluarga Berencana atau BKKBN telah melaksanakan program GenRe (Generasi Berencana). Program tersebut bertujuan untuk menyiapkan kehidupan berkeluarga bagi remaja melalui pemahaman tentang pendewasaan usia perkawinan. Adanya program tersebut diharapkan mampu meningkatkan pemahaman remaja agar mampu menyiapkan diri secara matang dan terencana baik dalam jenjang pendidikan, karir hingga menikah. Preferensi jumlah anak digunakan sebagai indikator dalam meramalkan tingkat kelahiran di masa depan dan penerimaan terhadap metode kontrasepsi. Pengukuran ini penting dilakukan untuk memprediksi perilaku kesuburan dan berguna dalam menyusun kebijakan kependudukan serta implementasi dari program keluarga berencana (Lunani, 2014).

Pada SKAP KKBPK 2018, dilaporkan bahwa tingkat fertilitas wanita di masing-masing provinsi dengan angka 
terendah berada di Provinsi Bali sebesar 2.2 anak per wanita (Badan Kependudukan dan Keluarga Berencana Nasional, 2018b). Dilaporkan pula hanya $17 \%$ remaja setuju untuk memiliki anak lebih dari dua, 40,4\% tidak setuju dan 41,6\% netral (Badan Kependudukan dan Keluarga Berencana Nasional, 2018c). Atas dasar tersebut, penelitian ini dimaksudkan untuk mengetahui faktor-faktor yang mempengaruhi preferensi jumlah anak ideal pada remaja belum kawin usia 15-24 tahun di Provinsi Bali.

\section{BAHAN DAN METODE}

Penelitian ini merupakan analisis data sekunder dari Survei Kinerja dan Akuntabilitas Program Keluarga Berencana dan Pembangunan Keluarga (SKAP KKBPK) tahun 2018 Komponen Remaja. Variabel yang diteliti dipilih dari kuesioner SKAP, remaja perempuan belum kawin usia 15-24 tahun dan remaja laki-laki belum kawin usia 15-24 tahun. Desain penelitian ini adalah cross-sectional. Penelitian ini menggunakan data sekunder sehingga penentuan besar sampel bergantung pada data SKAP KKBPK 2018. Berdasarkan data SKAP KKBPK 2018, jumlah sampel remaja untuk Provinsi Bali yakni 632 responden yang terdiri dari 334 remaja perempuan dan 298 remaja laki-laki.

Variabel bebas atau independen yang diamati dalam penelitian ini antara lain jenis kelamin, umur, tempat tinggal, pendidikan, kuintil kekayaan, keterpaparan remaja terhadap informasi kesehatan reproduksi dan keterpaparan remaja terhadap sumber informasi kependudukan. Sementara variabel tergantung atau dependennya adalah keinginan keluarga menginginkan banyak anak (>2). Data yang diperoleh kemudian dilakukan uji chi square untuk menguji hubungan atau pengaruh dan untuk mengukur kuatnya hubungan antara variabel. Kemudian dilakukan analisa multivariat menggunakan regresi logistik untuk mengetahui variabel yang memiliki probabilitas dalam mempengaruhi preferensi remaja dalam keinginan memiliki jumlah anak ideal.

\section{HASIL}

Gambaran Karakteristik Sosio Demografi Remaja Usia 15-24 Tahun di Provinsi Bali.

Sebagian besar responden merupakan remaja laki-laki (52.8\%) dengan rerata umur adalah 18.56 tahun. Tingkat pendidikan responden paling banyak oleh lulusan SLTA yakni 68.5\% dengan mayoritas daerah tempat tinggal berada di perkotaan (68.7\%). Berdasarkan kuintil kekayaan, persentase responden terbanyak berada pada kuintil kekayaan teratas sebesar $34.5 \%$.

\section{Akses Pelayanan Informasi Cara} Mencegah Kehamilan/KB dan Sistem Reproduksi Pada Remaja di Provinsi Bali

Berdasarkan analisis univariat yang dilakukan, diketahui bahwa seluruh responden $(100 \%)$ baik remaja dan lakilaki pernah mendengar/melihat/membaca informasi berkaitan dengan KB dan KRR (Kesehatan Reproduksi Remaja). Akses pelayanan informasi mengenai KB dan KRR paling banyak diperoleh responden melalui televisi sebesar $84.2 \%$ (KB) dan $89.2 \%$ (KRR) diikuti oleh pendidikan formal sebesar $87 \%$ (KRR). 
Responden remaja perempuan diketahui memiliki persentase lebih tinggi dibandingkan remaja laki-laki dalam memperoleh informasi mengenai GenRe (Generasi Berencana) sebesar 47.3\%. Untuk informasi ini, akses pelayanan informasi yang paling banyak digunakan oleh responden berasal dari pendidikan formal sebesar $80.8 \%$. Begitu pula untuk informasi yang berkaitan dengan PIK-R (Pusat Informasi dan Konseling Remaja), dilaporkan bahwa responden remaja perempuan lebih mengetahui dibanding remaja laki-laki dengan persentase $44.3 \%$. Untuk informasi PIK-R, remaja paling banyak memperoleh informasi dari teman/tetangga/saudara sebesar $66.8 \%$ dan pendidikan formal hanya $56.9 \%$.

\section{Preferensi Jumlah Anak Pada Remaja} Perempuan dan Laki-laki Usia 15-24 Tahun Berdasarkan Karakteristik Sosio Demografi

Preferensi jumlah anak yang diinginkan remaja diperoleh dengan menanyakan "bagaimana pendapat anda jika keluarga menginginkan banyak anak (>2 anak)?" kepada seluruh responden remaja berusia 15-24 tahun yang belum menikah.

Tabel 1. Preferensi jumlah anak pada remaja perempuan dan laki-laki usia 15-24 tahun berdasarkan karakteristik sosio demografi

\begin{tabular}{|c|c|c|c|c|c|c|}
\hline \multirow[t]{2}{*}{ Variabel } & \multicolumn{2}{|c|}{ Jumlah anak >2 } & \multirow[t]{2}{*}{ OR } & \multirow[t]{2}{*}{ Nilai P } & \multicolumn{2}{|c|}{$95 \% \mathrm{CI}$} \\
\hline & Ya (\%) & Tidak (\%) & & & LL & UL \\
\hline $\begin{array}{l}\text { Jenis Kelamin } \\
\text { - } \quad \text { Laki-laki } \\
\text { - } \quad \text { Perempuan }\end{array}$ & $\begin{array}{l}46(41.4) \\
65(58.6)\end{array}$ & $\begin{array}{l}288(55.3) \\
233(44.7)\end{array}$ & 1.747 & 0.008 & 1.153 & 2.646 \\
\hline $\begin{array}{cc}\text { Umur } & \\
\bullet & 15-19 \\
\bullet & 20-24 \\
\end{array}$ & $\begin{array}{l}81(73.0) \\
30(27.0) \\
\end{array}$ & $\begin{array}{l}334(64.1) \\
187(35.9) \\
\end{array}$ & 0662 & 0.075 & 0.419 & 1.043 \\
\hline $\begin{array}{l}\text { Pendidikan } \\
\text { - } \quad<\text { perg. tinggi } \\
\text { - } \text { Diploma- } \\
\text { perguruan } \\
\text { tinggi }\end{array}$ & $\begin{array}{l}100(90.0) \\
11(10.0)\end{array}$ & $\begin{array}{l}464(89.0) \\
57(11.0)\end{array}$ & 0.895 & 0.75 & 0.453 & 1.769 \\
\hline $\begin{array}{ll}\text { BPJS } & \text { Kesehatann(JKN } \\
\text { PBI) } & \\
\text { - } & \text { Tidak } \\
\text { - } & \text { Ya } \\
\end{array}$ & $\begin{array}{l}86(77.4) \\
25(22.56)\end{array}$ & $\begin{array}{l}365(70.0) \\
156(30.0)\end{array}$ & 0.68 & 0.118 & 0.42 & 1.103 \\
\hline $\begin{array}{l}\text { BPJS Kesehatan(JKN } \\
\text { Non-PBI) } \\
\text { - Tidak } \\
\text { - Ya }\end{array}$ & $\begin{array}{l}70(63.0) \\
41(37.0)\end{array}$ & $\begin{array}{l}321(61.6) \\
200(38.4)\end{array}$ & 0.94 & 0.775 & 0.615 & 1.436 \\
\hline $\begin{array}{c}\text { Tempat tinggal } \\
\text { - Kota } \\
\text { - Desa }\end{array}$ & $\begin{array}{l}81(73.0) \\
30(27.0)\end{array}$ & $\begin{array}{l}353(67.8) \\
168(32.2)\end{array}$ & 0.778 & 0.283 & 0.493 & 1.230 \\
\hline
\end{tabular}


Berdasarkan analisis yang dilakukan, remaja perempuan (58.6\%) lebih menginginkan untuk memiliki anak >2 dibandingkan remaja laki-laki (41.4\%) dengan nilai $\mathrm{p} \leq 0.008 ; 95 \% \mathrm{CI}=1.153-2.646$. Peluang remaja perempuan untuk menginginkan anak $>2$ adalah 1.7 kali lipat dibandingkan remaja laki-laki. Variabel sosio demografi lainnya seperti umur, tingkat pendidikan, kuintil kekayaan, serta daerah tempat tinggal tidak bermakna secara signifikan terhadap preferensi remaja dalam keinginan memiliki anak.

Preferensi Jumlah Anak Berdasarkan Akses Pelayanan Informasi Cara Mencegah Kehamilan/KB dan Sistem Reproduksi pada Remaja di Provinsi Bali

Berdasarkan akses pelayanan informasinya, preferensi jumlah anak yang diinginkan oleh remaja di Provinsi Bali dapat dilihat pada tabel 2 di bawah ini.

Tabel 2. Preferensi jumlah anak berdasarkan akses pelayanan informasi cara mencegah kehamilan/kb dan sistem reproduksi

\begin{tabular}{|c|c|c|c|c|c|c|}
\hline \multirow{2}{*}{ Variabel } & \multicolumn{2}{|c|}{ Jumlah anak $>2$} & \multirow[t]{2}{*}{ OR } & \multirow[t]{2}{*}{ Nilai P } & \multicolumn{2}{|c|}{$95 \%$ CI } \\
\hline & Ya & Tidak & & & LL & UL \\
\hline \multicolumn{7}{|l|}{ Informasi KB } \\
\hline \multicolumn{7}{|l|}{ Televisi } \\
\hline - Tidak & $24(21.6)$ & $76(14.6)$ & \multirow{2}{*}{0.619} & 0.067 & \multirow[t]{2}{*}{0.371} & \multirow[t]{2}{*}{1.034} \\
\hline - Ya & $87(78.4)$ & $445(85.4)$ & & & & \\
\hline \multicolumn{7}{|l|}{ Teman } \\
\hline - Tidak & $40(36.0)$ & 201 & \multirow{2}{*}{1.115} & 0.617 & \multirow[t]{2}{*}{0.728} & \multirow[t]{2}{*}{1.707} \\
\hline - Ya & $71(64.0)$ & 320 & & & & \\
\hline \multicolumn{7}{|l|}{ Guru } \\
\hline - $\quad$ Tidak & $48(43.2)$ & 278 & 1.502 & 0.054 & 0.993 & 2.270 \\
\hline - $\mathrm{Ya}$ & $63(56.8)$ & 243 & & & & \\
\hline \multicolumn{7}{|l|}{ Informasi KRR } \\
\hline \multicolumn{7}{|l|}{ Televisi } \\
\hline - Tidak & $16(14.4)$ & 52 & 0.658 & 0.171 & 0.361 & 1.202 \\
\hline - Ya & $95(85.6)$ & 469 & & & & \\
\hline \multicolumn{7}{|l|}{ Guru } \\
\hline - Tidak & $17(15.3)$ & 96 & 1.249 & 0.438 & 0.712 & 2.191 \\
\hline - Ya & $94(84.7)$ & 425 & & & & \\
\hline \multicolumn{7}{|c|}{ Pendidikan formal } \\
\hline - Tidak & $12(10.8)$ & 70 & 1.280 & 0.456 & 0.669 & 2.452 \\
\hline - Ya & $99(89.2)$ & 451 & & & & \\
\hline \multicolumn{7}{|l|}{ Informasi GenRe } \\
\hline \multicolumn{7}{|l|}{ Televisi } \\
\hline - Tidak & $15(30.6)$ & $68(28.0)$ & 0.881 & 0.710 & 0.451 & 1.719 \\
\hline - Ya & $34(69.4)$ & $175(72.0)$ & & & & \\
\hline $\begin{array}{c}\text { Guru } \\
\text { • Tidak }\end{array}$ & $14(28.6)$ & $70(28.8)$ & 1.012 & 0.974 & 0.513 & 1.995 \\
\hline
\end{tabular}


- Ya

Pendidikan formal

- Tidak

$35(71.4)$

- Ya

$10(20.4)$

39 (79.6)

Informasi PIK-R

Guru

- Tidak

$32(43.8)$

$167(47.4)$

1.157

0.574

0.696

1.921

- Ya

$41(56.2)$

Teman

Pendidikan formal
- Tidak

$22(30.1)$

$51(69.9)$

- Ya

- Tidak

$30(41.1)$

$43(58.9)$

$119(33.8)$

1.184

0.545

0.685

2.045

$233(66.2)$

- Ya

1.102

0.71

0.661

1.838
Hasil analisis menunjukkan bahwa akses pelayanan informasi untuk mencegah kehamilan/KB dan sistem reproduksi pada remaja tidak berpengaruh secara signifikan terhadap preferensi remaja. Hal ini dilihat dari nilai $\mathrm{p}>0.05$ dengan rentang derajat kepercayaan 95\% yang berada pada rentang $0-1$.
Faktor yang Mempengaruhi Preferensi Jumlah Anak pada Remaja Perempuan dan Laki-laki Usia 15-24 Tahun di Provinsi Bali

Analisis multivariat digunakan untuk memperoleh faktor yang paling memberikan pengaruh terhadap preferensi jumlah anak pada remaja di Provinsi Bali.

Tabel 3. Faktor yang mempengaruhi preferensi jumlah anak pada remaja perempuan dan

\begin{tabular}{lcccc}
\multicolumn{1}{c}{ laki-laki } & & & \\
\multicolumn{1}{c}{ Variabel } & Nilai P & OR & \multicolumn{3}{c}{ 95\% CI } \\
\cline { 4 - 5 } & & & LL & UL \\
\hline Kelompok umur & 0.065 & 1.563 & 0.972 & 2.511 \\
Jenis kelamin & 0.012 & 1.722 & 1.127 & 2.629 \\
Sumber informasi KB: & & & & \\
- Televisi & 0.043 & 1.729 & 1.017 & 2.937 \\
- Pamflet/leaflet/brosur & 0.002 & 0.444 & 0.265 & 0.747 \\
- Poster & 0.276 & 0.783 & 0.504 & 1.216 \\
\hline
\end{tabular}

Hasil analisis di atas menunjukkan jenis kelamin merupakan variabel yang berpengaruh secara signifikan terhadap keinginan remaja untuk memiliki anak lebih dari dua dilihat (nilai $\mathrm{p}<0.005$; OR 1.722; dan 95\% CI 1.127 - 2.629). Artinya, variabel jenis kelamin akan meningkatkan peluang remaja untuk memiliki anak lebih dari dua sebesar 1.722 kali.

Jenis media komunikasi yang digunakan dalam penyampaian informasi mencegah kehamilan/KB dan kesehatan reproduksi diketahui juga memberikan pengaruh secara signifikan. Televisi 
merupakan media komunikasi yang dapat meningkatkan peluang remaja sebesar 1.729 kali lipat untuk mempengaruhi preferensi remaja (nilai $\mathrm{p}<0.005$ dan $95 \% \mathrm{CI}$ 1.017 - 2.937). Hasil penelitian ini juga memperlihatkan adanya peran media informasi yang lebih efektif dalam menurunkan keinginan remaja untuk memiliki anak lebih dari dua atau sebagai variabel yang bersifat protektif (nilai p<0.05; OR 0.444; 95\%CI 0.265 - 0.747). Media yang dimaksud adalah pamflet/leaflet/brosur.

\section{PEMBAHASAN}

Penelitian ini memperlihatkan preferensi remaja dalam keinginan memiliki anak di masa depan dilihat dari berbagai faktor seperti karakteristik demografi, akses informasi mencegah kehamilan/KB dan kesehatan reproduksi. Berdasarkan hasil, jenis kelamin diketahui mempengaruhi preferensi remaja dalam menentukan jumlah anak yang diinginkan. Remaja perempuan memiliki peluang yang lebih besar untuk menginginkan anak lebih dari dua. Hasil penelitian lain memperlihatkan preferensi jumlah ideal anak dipengaruhi oleh tingkat pendidikan, lokasi tempat tinggal, dan kuintil kekayaan. Sementara pada konteks remaja, rata-rata jumlah anak yang dianggap ideal adalah 2.2 hingga 2.5 (Handayani and Najib, 2019; Handayani and Nasirin, 2020). Jumlah tersebut didasarkan pada pandangan remaja terhadap manfaat anak seperti membantu orang tua, kebahagiaan keluarga, penerus keturunan, dan jaminan hari tua (Listyaningsih and Sumini, 2015).

Jika dilihat dalam konteks kehidupan masyarakat Bali, kondisi ini muncul sebagai akibat masyarakat yang masih sangat menjaga budaya patriarki. Budaya tersebut menempatkan posisi lakilaki lebih tinggi dibandingkan perempuan (Rahmawati, 2016). Selain itu, terdapat kekeliruan dalam pelaksanaan konsep purusa dan pradana di Bali yang memandang kedudukan laki-laki lebih istimewa dibanding perempuan (Rahmawati, 2016). Kondisi tersebut pada akhirnya secara tidak langsung memaksa perempuan untuk "terus" bereproduksi sampai melahirkan anak laki-laki. Hasil penelitian ini sesuai dengan hasil penelitian lainnya di Bali yang menunjukkan bahwa jumlah anak dalam satu keluarga dipengaruhi oleh kebiasaan daerah dan dorongan orang tua masingmasing pasangan (Sudibia, Dewi and Rimbawan, 2015).

Secara tidak langsung, hal ini dapat meningkatkan risiko kesehatan yang akan dialami perempuan. Tingginya frekuensi melahirkan dua hingga empat kali atau lebih dapat meningkatkan risiko terhadap komplikasi di masa kehamilan dan persalinan baik bagi ibu maupun anaknya. Komplikasi tersebut antara lain anemia saat hamil, hipertensi, diabetes mellitus, pendarahan antepartum, plasenta previa dan plasenta abruption (Akhtar et al., 2018; Obs et al., 2018; Ajong et al., 2019). Pada saat persalinan, risiko yang mungkin dialami seperti pendarahan postpartum, melahirkan secara caesar (cesarean section), malpresentation atau posisi janin abnormal (Afolabi and Adeyemi, 2013; Ahmed, 2013; Alsammani and Ahmed, 2015). Sementara risiko yang mungkin dialami bayi yakni bayi lahir prematur, asfiksia, berat badan lahir rendah (BBLR) dan kematian bayi (Al- 
Shaikh et al., 2017).

Meski dipandang sebagai faktor risiko terhadap kesehatan namun hal ini kurang didukung oleh kebijakan pemerintah khususnya pemerintah Provinsi Bali. Hal tersebut dilihat dari diterbitkannya Instruksi Gubernur Bali Nomor 1545 Tahun 2019 tentang Sosialisasi Program Keluarga Berencana Krama Bali yang menganjurkan masyarakat Bali untuk memiliki anak lebih dari dua. Diterbitkannya instruksi tersebut sebagai upaya dalam melestarikan nama khas Bali yakni Komang dan Ketut.

Lebih lanjut, dari hasil analisis multivariat diketahui bahwa faktor risiko yang berpeluang meningkatkan preferensi remaja dalam menginginkan jumlah anak adalah televisi. Sebagai salah satu media komunikasi massa, televisi telah mengalami perubahan atau transformasi dari caranya mengkomunikasikan informasi kepada masyarakat. Konten informasi yang disampaikan umumnya mengikuti ekspektasi penonton. Sebuah penelitian di Amerika menunjukkan remaja hanya menonton siaran televisi yang sesuai dengan kepribadiannya. Hal ini karena konten siaran tersebut mendukung remaja dalam membangun identitasnya (Bleakly and Ellithorpe, 2016). Penelitian lain menunjukkan media televisi berpengaruh secara signifikan dalam membentuk dan mempengaruhi remaja dalam menggunakan alat kontrasepsi (Ajaero et al., 2016). Meski hasil penelitian sebelumnya tidak sesuai dengan hasil yang diperoleh, hal tersebut dapat menjadi sebuah masukan dimana penggunaan media televisi masih layak digunakan sebagai sarana pemberian informasi dan edukasi bagi remaja. Untuk itu perlu dilakukan penyesuaian konten yang disiarkan dengan kebutuhan remaja.

Selain mengetahui faktor yang meningkatkan preferensi remaja, hasil penelitian ini juga berhasil memperoleh faktor yang dapat menurunkan preferensi remaja dalam menentukan jumlah anak. Faktor yang dimaksud adalah pamflet/leaflet/brosur. Meskipun media ini terlihat kurang menarik bagi remaja namun dari hasil yang diperoleh terlihat bahwa penggunaannya dapat menurunkan atau mencegah keinginan remaja untuk memiliki anak lebih dari dua. Media pamflet/leaflet/brosur sebagai media komunikasi memasukkan berbagai unsur yang dapat mempengaruhi pembacanya seperti ilustrasi, permainan warna dan grafis (Ruyadi, Winoto and Komariah, 2017). Penelitian yang dilakukan tahun 2018 mengenai penggunaan media komunikasi,menujukkanpamflet/leaflet/bro sur dapat meningkatkan pengetahuan siswa SMA terhadap kesehatan reproduksi meskipun media visual lainnya seperti video lebih efektif (Alini and Indrawati, 2018). Walaupun hasil penelitian ini berbeda dengan penelitian sebelumnya, hal ini memperlihatkan bahwa remaja di Provinsi Bali masih memiliki ketertarikan terhadap media cetak untuk memperoleh informasi kesehatan.

\section{KESIMPULAN DAN SARAN}

Remaja perempuan memiliki peluang yang lebih tinggi untuk menginginkan anak lebih dari dua dibandingkan remaja laki-laki. Jenis 
kelamin dan televisi merupakan faktor dominan yang mempengaruhi preferensi remaja di Provinsi Bali dalam menginginkan jumlah anak ideal. Akses pelayanan informasi sistem reproduksi tidak berpengaruh secara signifikan terhadap preferensi remaja. Sumber informasi cara mencegah kehamilan melalui media pamflet/leaflet/brosur diketahui sebagai faktor protektif dalam mengendalikan keinginan remaja memiliki jumlah anak lebih dari dua. Berkaitan hal tersebut, adapun sarannya yakni melibatkan keluarga dalam pemberian informasi kesehatan seperti cara mencegah kehamilan dan kesehatan reproduksi. Kemudian, perlu dilakukannya pembaharuan metode pendekatan terhadap remaja dengan memanfaatkan teknologi informasi internet seperti media sosial dalam menyediakan informasi kesehatan baik KB, KRR, PIK-R, dan GenRe.

\section{UCAPAN TERIMA KASIH}

Peneliti mengucapkan terima kasih kepada Badan Kependudukan dan Keluarga Berencana (BKKBN) Perwakilan Provinsi Bali yang telah mengijinkan dan memberikan dukungan dalam hal pendanaan terhadap penelitian ini.

\section{DAFTAR PUSTAKA}

Afolabi, A. F. and Adeyemi, A. S. (2013) 'Extreme grandmultiparity: Is it an obstetric risk factor?', Journal of Obstetrics and Gynecology, 3, pp. 411415. doi: 10.1016/S0301-2115(01)004985.

Agushybana, F. et al. (2019) 'Desired Numbers of Children and Related
Factors among Adolescents in Indonesia', Mediterranean Journal of Social Sciences, 9(5), pp. 53-62. doi: 10.2478/mjss-2018-0138.

Ahmed, I. A. M. (2013) 'Maternal and fetal outcome of grandmultipara in comparison to multiparous woman in two hospital in Khartoum State', Journal of Dental and Medical Sciences, 9(6), pp. 22-42. doi: 10.9790/08530962242.

Ajaero, C. K. et al. (2016) 'Access to mass media messages, and use of family planning in Nigeria: a spatiodemographic analysis from the 2013 DHS', BMC Public Health. BMC Public Health, 16(427), pp. 1-10. doi: 10.1186/s12889-016-2979-z.

Ajong, A. B. et al. (2019) 'Grand multiparity in rural Cameroon: Prevalence and adverse maternal and fetal delivery outcomes', BMC Pregnancy and Childbirth. BMC Pregnancy and Childbirth, 19(1), pp. 1-7. doi: 10.1186/s12884-019-2370-z.

Akhtar, R. et al. (2018) 'Frequency of maternal and fetal outcome in grand multipara women', Khyber Journal of Medical Sciences, 11(3), pp. 376-379.

Al-Shaikh, G. K. et al. (2017) 'Grand multiparity and the possible risk of adverse maternal and neonatal outcomes: A dilemma to be deciphered', BMC Pregnancy and Childbirth. BMC Pregnancy and Childbirth, 17(1), pp. 1-7. doi: 10.1186/s12884-017-1508-0.

Alini and Indrawati (2018) 'Efektivitas promosi kesehatan melalui audio visual dan leaflet tentang SADARI (pemeriksaan payudara sendiri) 
terhadap peningkatan pengetahuan remaja putri tentang SADARI di SMAN 1 Kampar tahun 2018', Jurnal Ners Universitas Pahlawan, 2(2), pp. 1-9. Alsammani, M. and Ahmed, S. (2015) 'Grand Multiparity: Risk Factors and Outcome in a Tertiary Hospital: a Comparative Study', Materia Socio Medica, 27(4), p. 244 . doi: 10.5455/msm.2015.27.244-247.

Badan Kependudukan dan Keluarga Berencana Nasional (2018a) Survei Demografi dan Kesehatan Indonesia, Riset Kesehatan Dasar 2018. doi: 1 Desember 2013.

Badan Kependudukan dan Keluarga

Berencana Nasional (2018b) Survei Kinerja dan Program KKBPK. Jakarta.

Badan Kependudukan dan Keluarga

Berencana Nasional (2018c) Survei Kinerja dan Program KKBPK. Edited by Kasmiyati et al. Jakarta: Badan Kependudukan dan Keluarga Berencana Nasional.

Badan Pusat Statistik (2010) Hasil Sensus Penduduk 2010: Data Agregat per Provinsi. Jakarta.

Badan Pusat Statistik (2015) Profil Penduduk Indonesia Hasil SUPAS 2015. Jakarta.

Badan Pusat Statistik (2018) Statistik Pemuda Indonesia. Jakarta.

Bleakly, A. and Ellithorpe, M. (2016) How are adolescent affected by what they watch on tv?, Annenberg School for Communication University of Pennsylvania. Available at: https://www.asc.upenn.edu/newsevents/news/how-are-adolescentsaffected-what-they-watch-tv.

Catherine, H. (2003) 'A new approach to explaining fertility patterns: preference theory', Population and Development Review Bulletin of the World Health Organization, 29(3), pp. 349-374. doi: $10.2307 / 3115278$.

DeVito, J. (2010) 'How adolescent mothers feel about becoming parent', Journal of Perinatal Education, 19(2), pp. 25-34. doi: 10.1624/105812410x495523.

Erfina, E. et al. (2019) 'Adolescent mothers' experiences of the transition to motherhood: an integrative review', International Journal of Nursing Sciences, 6(2), pp. 221-228. doi: 10.1016/j.ijnss.2019.03.013.

Handayani, A. and Najib, N. (2019) 'Keinginan memiliki anak berdasarkan teori pilihan rasional (analisis data SDKI tahun 2017)', EMPATI-Jurnal Bimbingan dan Konseling, 6(2), pp. 3140. doi: 10.26877/empati.v6i2.4277.

Handayani, B. N. and Nasirin, C. (2020) 'Pengaruh sosial demografi terhadpa jumlah anak yang diinginkan di NTB (analisis data SDKI 2017)', Jurnal Midwifery Update (MU), 1(2), p. 70. doi: 10.32807/jmu.v1i2.63.

Herrman, J. W. (2008) 'Adolescent perceptions of teen births', JOGNN Journal of Obstetric, Gynecologic, and Neonatal Nursing. Elsevier Masson SAS, 37(1), pp. 42-50. doi: 10.1111/j.1552-6909.2007.00201.x.

Listyaningsih, U. and Sumini, S. (2015) 'Jumlah anak ideal menurut remaja di Daerah Istimewa Yogyakarta', Populasi, 23(2), pp. 38-54. doi: 10.22146/jp.15694.

Lunani, L. L. (2014) Determinantf of fertility preferences among currently married 
women in Kenya. University of Nairobi.

Nicolas W. Cortes-Penfield, Barbara W. Trautner, R. J. (2017) 'Pregnant adolescent women's perceptions of depression and psychiatric services in the United States', Physiology \& behavior, 176(5), pp. 139-148. doi: 10.1016/j.physbeh.2017.03.040.

Obs, G. et al. (2018) 'Frequency and Maternal Outcome Following Placental Abruption', Journal of Saidu Medical College, 18(2), pp. 156-160.

Rahmawati, N. N. (2016) 'Perempuan Bali dalam Pergulatan Gender (Kajian Budaya, Tradisi, dan Agama Hindu)', Jurnal Studi Kultural, 1(1), pp. 58-64. Available at: https://journals.an1mage.net/index.ph p/ajsk/article/view/50.

Ruyadi, I., Winoto, Y. and Komariah, N. (2017) 'Media komunikasi dan informasi dalam menunjang kegiatan penyuluhan pertanian', Jurnal Kajian Informasi \& Perpustakaan, 5(1), pp. 3750.

Sari, A. A. (2015) ‘Determinan Preferensi Jumlah Anak Pada Remaja (15-24 Tahun) Di 10 Provinsi Penyangga (Analisis Data SDKI 2012)', pp. 1-22.

Sudibia, I. K., Dewi, I. G. A. M. and Rimbawan, I. N. D. (2015) 'Faktorfaktor yang mempengaruhi menurunnya usia kawin pertama di Provinsi Bali', Kependudukan dan Pengembangan Sumber Daya Manusia, XI(2), pp. 43-58.

The World Bank (2006) World Development Report 2007: Development and the next generation, World Development Report 2007. Washington DC. doi: 10.1596/978-0-8213-6541-0.
United nations population fund (2017) 'Population Maternal and newborn health'. 